Tumou Tou, Volume VII, Nomor 2:143-156

ISSN 2355-3308 (Cetak), ISSN 2745-9527 (Online)

\title{
TANGGUNG JAWAB GURU SEKOLAH MINGGU DALAM KEHIDUPAN SPIRITUAL ANAK
}

\author{
Susan Bawole \\ Mahasiswa Pascasarjana Teologi IAKN Manado \\ susanbawole90@gmail.com
}

Diterima 16 April 2020

Disetujui 13 Mei 2020

\begin{abstract}
Abstrak
Tugas dan tanggung jawab Guru sekolah minggu sangatlah berat di zaman yang semakin maju, guru sekolah minggu mempunyai peran yang penting dalam perkambangan spiritual anak di masa ini. Guru sebagai alat Tuhan untuk mendidik anak dalam lingkup gereja. Namun tidak begitu baik adanya di karenakan banyak guru yang melalaikan Tugasnya untuk melayani anak-anak. banyak guru hanya sekedar datang tapi tidak melakukan tanggung jawabnya dengan benar, tidak mempunyai persiapan yang matang. Guru sebegai ujung tombak dalam mengajar anak jika tidak melaksanakan Tugas dengan baik, akan di pastikan tidak ada lagi anak-anak yang akan datang ke gereja di masa yang datang. Jurnal ini mempunyai tujuan untuk memberikan informasi bagaimana sesungguhnya Tugas dari guru sekolah minggu dalam pembentukan spiritual anak.
\end{abstract}

Kata kunci : Tanggung Jawab Guru, kehidupan spiritual anak, Sekolah minggu

\section{PENDAHULUAN}

Orang tua dan gembala memiliki tanggung jawab yang besar atas pendidikan anak. Namun, para guru sekolah minggu pun sesunggunya memiliki tanggung jawab yang besar dalam membina anak. Setiap guru sekolah minggu harus sadar bahwa Allah menciptakan anak-anak begitu rupa dan unik. Mereka mempunyai kekhasan masing-masing karena Allah menciptakan mereka sebagai ciptaaanNya yang khusus. Oleh karena itu, Guru sekolah minggu tidak boleh mengajar atau membelajarkan anak-anak seperti orang dewasa. Seorang Guru sekolah minggu perlu memahami sungguhsungguh bahwa anak-anak adalah pelajar yang Allah percayakan untuk dilayani. Ini adalah salah satu tanggung jawab yang penting dari tugas pelayanan mereka untuk membantu 
mencerdaskan anak sekolah minggu di dalam Tuhan.( Junihot Simanjuntak, 2012, p. 9). Guru sekolah minggu harus mampu menunjukkan teladan yang baik bagi anak didik, karena keteladanan dari seorang guru sangat mempengaruhi pendidikan dan pertumbuhan rohani anak. (Ralph M. Ringgs, 1978, p. 36). Guru seharusnya menyadari bahwa mengajar merupakan suatu pekerjaan yang tidak sederhana dan mudah. Sebaliknya mengajar sifatnya sangat kompleks karena melibatkan aspek pedagogig, psikologis dan didaktis secara bersamaan. (Ngainun Naim, 2011, p 15). Dari hasil wawancara, bisa disimpulkan bahwa secara khusus dalam tata gereja tidak tercantum ketiga aspek ini tetapi dalam program jemaat, program sinode, lewat seminar ketiga aspek ini dibahas agar guru sekolah minggu tahu bagaimana mendidik anak sesuai dengan kondisinya. faktor-fakor itu memang seharusnya dimiliki oleh seorang guru sekolah minggu agar supaya hasilnya maksimal. (Wawancara dengan Pdt Meydi Koroh, 12 juni 2015). Panggilan sebagai pelayan atau menjadi Guru sekolah minggu merupakan karunia dari Allah dan mengajar adalah tugas yang paling mulia karena bisa menuntun anak-anak kejalan yang benar dan mengajar anakanak pada hal-hal yang baik.

Akan tetapi ketika banyak guru sekolah minggu tidak melaksanakan tugas sesuai dengan Alkitab, menjadi seorang guru sekolah minggu seharusnya mempunyai pengetahuan tentang anak, paham tentang firman Allah dan mempunyai perilaku yang baik yang sesuai dengan firman Allah, dan karakter sesuai dengan kehendak Allah. Hal-hal yang diajarkan guru sekolah minggu kepada anak-anak akan diingat dengan jelas sebab itu sebagai pendidik haruslah mengajarkan yang baik pada anak-anak sehingga tujuan sekolah minggu bisa tercapai sesuai dengan kehendak Allah. Oleh sebab itu tugas seorang guru sekolah minggu bukan hanya sekedar mengajar Alkitab saja tapi bagaimana hidup sesuai dengan kehendak Allah.

$$
\text { Seharusnya guru sekolah }
$$
minggu selain memiliki kewajiban untuk mengajar tapi guru sekolah minggu juga harus memperhatikan pribadinya yang juga menentukan keberhasilan dalam kedewasaan iman anak-anak sekolah minggu. Sikap memberikan pendidikan yang benar 
sejak dini akan banyak mempengaruhi kehidupan anak-anak dalam segala segi, sebab pendidikan yang telah diberikan dapat membentuk watak, kepribadian, tingkah laku dan juga kerohaniannya kearah yang benar hingga pada masa mudanya kelak. Melihat kenyataan sekarang sebenarnya gereja harus aktif dalam pengembangan spiritual bukan hanya teori saja. Gereja haruslah memperhatikan usaha yang dilakukan bagi guru sekolah minggu sebagai pendidik yakni gereja harus mempersiapkan dan menyediakan tenaga pengajar yang terampil dibidangnya, mempunyai pengetahuan yang baik tentang anak sekolah minggu. Sebenarnya gereja harus memilih tenaga guru sekolah minggu yang tepat dan benar sebab akan berdampak bagi anakanak sekolah minggu itu sendiri. Pemilihan guru sekolah minggu yang benar dan tepat akan berdampak positif bagi pertumbuhan spiritual dari anakanak. Sebaliknya ketika gereja memiliki guru sekolah minggu yang tidak tepat maka akan berdampak negatif. Tujuan Penelitian Untuk mengetahui bagaimana guru sekolah minggu menjalankan tanggung jawab terhadap pembentukan kehidupan spiritual anak di jemaat.

\section{METODE}

Dalam penelitian ini penulis menggunakan metode penelitian kualitatif karena metode penelitian yang digunakan untuk meneliti pada kondisi yang alamiah, (sebagai lawanya adalah eksperimen) dimana peneliti adalah sebagai instrumen kunci, teknik pengumpulan data dilakukan secara triangulasi (Gabungan), analisis data bersifat induktif dan hasil penelitian kualitatif lebih menekankan makna dari pada generalisasi. Objek dalam penelitian kualitatif adalah objek alamiah, atau natural setting. Sehingga metode penelitian ini sering disebut sebagai metode naturalistik. (Sugiyono, Bandung 2009).

\section{HASIL}

Gereja merupakan tempat dimana anak-anak menemukan diri mereka bebas dalam bernyanyi dan memuji Tuhan, namun gereja di masa ini tidak terlalu memusatkan pelayanan pada anak-anak, gereja semakin sibuk dengan menyampaikan firman di tempat-tempat yang belum terjangkau tanpa melihat ada berbagai macam ragam yang harus di benah untuk 
menumbuhkan iman serta spiritual anak-anak.

Dalam segi kehidupan spiritual anak, tidak lepas dari kerja kerasnya guru sekolah minggu, dalam titik tertentu guru sekolah minggu menjadi penentu masa depan gereja di masa yang akan datang, akan tetapi banyak guru sekolah minggu tidak menjalankan tugasnya dengan baik, diberbagai gereja tidak dapat di pungkiri bahwa sekolah minggu hanya sebagai ajang pertemuanan anak-anak sambil bermain, seharusnya sekolah minggu sebagai perantara anak-anak mengenal Allah akan tetapi hal ini semakin hari semakin tidak bisa di bending lagi bahwa sekolah minggu tidak berfungsi sebagaimana semestinya. Hal yang bisa dilakukan gereja sekarang ini adalah bagaimana terus membenah dan memberikan pelatihan kedapa guruguru sekolah minggu sehingga dapat melakukan pekerjaannya dengan baik dan benar sesuai dengan yang telah di firmankan dalam Alkitab.

\section{PEMBAHASAN}

\section{Pengertian Guru Sekolah Minggu}

Guru sekolah adalah orang yang dipilih dan ditetapkan oleh Allah untuk menjadi kawan sekerjan-Nya melayani
Anak-anak dan memelihara anak-anak serta memberikan pengajaran yang baik kepada anak-anak. Menurut kamus besar bahasa Indonesia “ Guru adalah orang yang pekerjaanya yaitu mengajar. (Kamus Besar Bahasa Indonesia, 2003, $\mathrm{p}$ 576). Penggerak dalam pelayanan sekolah minggu adalah guru sekolah minggu, dimana dalam pelayanan tersebut guru harus mampu untuk membina anak-anak ke gereja pada usia dini. Dalam perspektif kristen guru merupakan pengajar yang memberikan pengajaran yang berkaitan dengan iman kristen. Guru harus perlu memahami pribadi Yesus sebagai guru yang harus di teladani dalam kehidupan sehari-hari terutama dalam melaksanakan tugas keguruan. (Andar Ismail, 2006, p 259). Menurut E.G. Homrighausen dan I.H. Enklaar "tugas guru dalam pendidikan agama sangat penting, dan tanggung jawabnya berat. Guru itu dipanggil untuk membagikan harta abadi. Dan dalam pekerjaannya ia menghadapi jiwa manusia yang besar di hadapan Allah." (E.G Homrighausen \& I.H Enklaar, 2011, p 165) Menurut George R. Knight hanya guru yang lahir baru yang bisa mentransmisikan kasih anugerah Tuhan pada orang lain atau melayani orang 
lain dalam anugerah tersebut (Khoe Yao Tung, 2013 p 318 ).

Mengacu pada pengertian di atas maka dapat disimpukan bahwa Guru sekolah minggu adalah seorang yang mengajarkan firman Tuhan, mengajarkan tentang kebaikan, dan mengajarkan tentang nilai-nilai kristiani pada anak-anak sekolah minggu.

\section{Tugas guru Sekolah Minggu}

Dalam melaksanakan tugasnya, seorang guru sekolah minggu dituntut untuk melaksanakan tugas sebagai berikut :

\section{Mengkomunikasikan hal yang benar}

Guru adalah teladan bagi para murid oleh karena itu, seorang guru harus mampu memperkatakan atau mengkomunikasikan hal yang benar. Kesaksian Alkitab dalam Kej 18:19, Allah memberikan tugas utama kepada Abraham, agar ia hidup menurut jalan yang telah di tentukan Tuhan dengan melakukan kebenaran dan keadilan. Anak-anak sebagai bagian dari integral gereja harus diajarkan tentang hal yang benar menurut Alkitab. Karena dengan memperkenalkan, mengkomunikasikan, dan mengajar hal yang benar, maka anak akan semakin mengenal kebenaran itu sendiri.

\section{Menjadi sumber berkat}

Guru sekolah minggu mengajar anak melalui cara-cara yang dapat dinikmati oleh anak secara langsung, melalui bercerita, bernyanyi, bermain dengan mereka sehingga ada sukacita dan menyenangkan. Perasaan sukacita dan menyenagkan akan meyakinkan bahwa setiap guru sekolah minggu telah dipakai Tuhan menjadi saluran berkat bagi anak-anak. Menjadi pelayan sekolah minggu berarti memperbolehkan diri sendiri untuk dipakai oleh Tuhan menjadi alat untuk memberitakan cinta kasih dan kebenaran-Nya.

\section{Melayani sesuai dengan kemampuan masing-masing}

Setiap orang diciptakan Tuhan mempunyai talenta dan kemampuan yang berbeda satu dengan yang lain. Melayani disekolah minggu tidak berarti harus dapat melakukan semua pelayanan seorang diri. Setiap orang terpanggil untuk saling melengkapi agar tidak ada seorang pun yang memegahkan diri sendiri namun melakukan tugas bersama-sama dan juga mengucap syukur kepada Tuhan karena semua guru dipakai untuk 
menjadi saluran berkat. (Andar Ismail, 2006, p .231)

\section{Tanggung Jawab Guru Sekolah Minggu}

Dapat diketahui bahwa tanggung Jawab itu adalah kesadaran manusia dan tingkah laku atau perbuatannya yang disengaja maupun tidak sengaja dan tanggung jawab juga berarti berbuat sebagai perwujudan kesadaran akan kewajiban. Tanggung jawab itu bersifat kodrat artinya sudah menjadi bagian kehidupan manusia bahwa setiap manusia itu mesti dibebani dengan tanggung jawab. ada beberapa tugas dan tanggung jawab Guru sekolah minggu :

Mendoakan anak-anak merupakan bagian penting yang harus dilakukan oleh seorang guru sekolah minggu untuk menjalin komunikasi dan keakraban dengan anak-anak dan orang tuanya.

Mengembalakan adalah tugas guru juga tidak hanya mengajar tetapi juga gembala bagi domba-dombanya. Seorang gembala yang baik mengenal dan mengasihi setiap dombanya. Dan tidak membiarkan seekor domba pun berada dalam kesulitan. (Erika Helena, $\&$ Sudi Ariyanto, 2003, p 20).

\section{Pemahaman tentang Kehidupan Spiritual}

\section{Pengertian Spiritual}

Spiritual berasal dari kata latin spiritus yang berarti roh, jiwa, semangat. Dari kata latin ini terbentuk kata prancis I'esprit dan kata bendanya ia Spiritualite. Dari kata ini kita mengenal kata inggris spirituality, yang dalam bahasa Indonesia kita jadikan kata spiritualitas. Dalam pecakapan sehari-hari spiritualitas merupakan kata yang dilawankan dengan kata "materia" atau "korporalitas" disini spiritualitas berarti bersifat atau berkaitan dengan roh yang berlawanan dengan materialitas. Bersifat atau berkaitan dengan kebendaan atau korporalitas yang berarti bersifat tubuh, badani, atau berkaitan dengan tubuh atau badan. Spiritualitas juga sering diartikan hidup saleh dan berbakti kepada Allah. Akhirnya spiritualitas juga sering dimengerti sebagai devosi (kebaktian yang tidak resmi), hidup batin, hidup rohani. Akan tetapi ketiga arti itu berkaitan namun, bukanlah arti mendasar dari istilah spiritualitas. Dalam arti sebenarnya, spiritualitas berarti hidup berdasarkan atau menurut roh. Dalam konteks hubungan dengan 
yang transenden, roh itu adalah roh Allah sendiri. Spiritualitas adalah hidup yang didasarkan pada pengaruh dan bimbingan roh Allah. (Agus M Harjana, 2005, p 64)

Arti kata spiritualitas sering kali disalah mengerti. Spiritualitas bukan berarti keaktifan dalam perkumpulan seksi kerohanian, bukan fenatisme beragama, bukan hyper relegius (menonjolkan hidup keberagamaan secara berlebihan), bukan agama secara emosional yang mengungkapkan emosi dan sentimen relegius secara mencolok, bukan kesalehan atau upaya hidup saleh, bukan juga askese jauh dari kehidupan hidup duniawi. Spiritualitas adalah kualitas gaya hidup seseorang sebagai hasil dari kedalaman pemahamannya tentang Allah secara utuh. Allah dipahami sebagai yang berada jauh di atas, tetapi juga sekaligus yang berada dekat di hati. Artinya, gaya hidup sehari-hari merupakan buah dari hubungnnya dengan Yesus. (Jhon M Nainggolan, 2007, p 123) Jadi spiritual merupakan anugarah Allah dinyatakan dalam kehidupan dan dijalani sebagai respon terhadap kerajaan Allah didalam Yesus Kristus

\section{Pendidikan Spiritual}

Menurut Susanne Johnson :

Naradidik : yang masuk dalam kategori naradidik adalah siapa saja yang ada dalam persekutuan di gereja. Termasuk mereka yang baru diperkenalkan kepada Kristus dan perlu diperkenalkan kembali.

Guru : siapa saja dapat berperan menjadi guru. Seluruh komunitas mengajar dengan pendeta dan pendidikan Kristen sebagai pemimpin. Guru adalah yang memberlakukan cerita itu bersama nara didik. Untuk itu gereja dapat memilih dan melatih orang-orang tertentu untuk menjadikan kader pemimpin. Jadi guru dan nara didik adalah rekan dalam pengembara.

Lokasi : adalah gereja. Seluruh kegiatan gereja adalah sebuah lingkungan hidup dari spiritualitas. Isi : Cerita Kristen : Alkitab; tradisi Kristen; liturgi, cerita yang berasal dari cerita pribadi, Cerita yang berasal dari konteks atau budaya masing-masing

Strategi dan metode: pendidikan Kristen dapat di gambarkan sebagai sebuah proses belajar mengajar yang dinamis dan disengaja dan melaluinya komunitas orang beriman diinisiasikan kepada partisipasi yang lebih kompleks 
dan setia dalam kegiatan Allah yang kratif dan membebaskan didunia. Pendidikan kristiani terdiri dari tiga proses yang saling berhubungan, di sengaja dan seumur hidup, dilaksanakan oleh komunitas orang beriman, melaluinya karakter kristen menerima bentuknya yang berbeda dan berorientasi seumur hidup dan melaluinya gereja lebih terinisiasi kedalam kerajaan Allah. Ketiga prose situ ialah ibadah, pengajaran dan praksis. (Daniel Nuhamara, p 9, )

Dengan melihat masalah yang terjadi dalam persekutuan anak sekolah minggu maka peneliti menggunakan pendekatan pendidikan kristiani menurut Jack L. Seymour :

Pendekatan intruksional merupakan pendekatan yang bertujuan untuk memampuhkan nara didik mendasari kehidupannya pada ajaranajaran Alkitab dan membangun hubungan antara isi dan ajaran tersebut dengan kehidupan.

Pendekatan perkembangan spiritualitas merupakan pendekatan yang bertujuan untuk membantu para nara didik meningkat aspek kehidupan diri mereka dan meresponya dengan tindakan terhadap sesama dan dunia.
Pendekatan komunitas iman merupakan pendekatan yang bertujuan untuk membangun komunitas yang memperlihatkan perkembangan manusia yang otentik dan membantu seseorang menciptakan sebuah komunitas.

Pendekatan transformasi merupakan pendekatan yang bertujuan membantu nara didik dan komunitas untuk menunjukkan adanya pembahasan sosial.

Pendidikan kristen adalah proses belajar-mengajar yang berdasarkan Alkitab, di mampuhkan oleh Roh Kudus. Berpusat pada Kristus, pendidikan kristen berusaha membimbing individu disemua level pertumbuhan lewat berbagai cara pengajaran ke arah penganalan dan pengalaman akan rencana dan tujuan Allah melalui Kristus dalam setiap aspek kehidupan. Pendidikan kristen adalah proses yang berpusat pada Kristus. Pendidikan kristen adalah mencipta ulang dan mengembangkan hubungan yang benar antara Allah dengan manusia, antara manusia dengan sesamanya.

Pendidikan adalah proses yang melibatkan kerja sama antara Tuhan dengan manusia dalam rangka 
menumbuhkan dan mengembangkan orang-orang dalam kehidupannya, yakni dalam hal pengenalan yang saleh, iman, pengharapan dan kasih melalui Kristus. Pendidikan kristen menghasilkan perubahan, pembaharuan, dan reformasi dalam diri individu, kelompok, oleh karena kuasa roh kudus sehingga membuat mereka semakin serupa dengan kehendak Allah. (W. Robert Pazmino, 2012 , p 119 )

Pemahaman tentang Anak Sekolah Minggu

Anak

Anak adalah karunia dari Tuhan dan sungguh suatu berkat yang diberikan Tuhan kepada manusia. (E. Daniel Fountain, 2013. p 1)

Anak adalah makhluk sosial seperti juga orang dewasa. Anak membutuhkan orang lain untuk membantu mengembangkan kemampuannya, karena anak lahir dengan segala kelemahan sehingga tanpa orang lain anak tidak mungkin dapat mencapai taraf kemanusiaan yang normal. Anak merupakan Makhluk yang membutuhkan pemeliharaan, kasih sayang, dan tempat bagi perkembangannya. Selain itu anak merupakan bagian dari keluarga, dan keluarga memberi kesempatan bagi anak untuk belajar tingkah laku yang penting untuk perkembangan yang cukup baik dalam kehidupan bersama. (UU perlindungan Anak, 2003, p 3)

\section{Perkembangan Anak menurut} Beberapa Ahli

Menurut Froebel masa anak tanggung mencakup usia 7 tahun - 10 tahun. Pada tahap ini dinamakan masa untuk belajar, karena pada tahap inilah anak memulai pengalaman belajar yang lebih formal berhasrat mengambil bagian dalam urusan keluarga rajin menolong orang lain, suka banyak mengajukan pertaanyaan. (Robert R. Boehlke, p 315)

Menurut Piaget masa anak tanggung mencakup usia $6-12$ tahun adanya korelasi positif yang tinggi antara keadaan jasmani dengan prestasi sekolah.

Sikap tunduk kepada peraturanperaturan permainan tradisional; Ada kecenderungan memuji diri sendiri, suka membanding-bandingkan dirinya dengan anak lain, kalau hal itu dirasanya menguntungkan; dalam hal ini ada kecenderungan untuk meremehkan anak lain, kalau tidak dapat menyelesaikan soal, maka soal itu 
dianggap tidak penting. Pada masa ini anak menghendaki nilai yang baik, tanpa mengingat apakah prestasinya memang pantas diberi nilai baik atau tidak

Adanya minat terhadap kehidupan praktis sehari-hari; Amat realistis, ingin tahu, ingin belajarMembutuhkan seorang guru atau orang dewasa untuk menyelesaikan tugas dan memenuhi keinginannya; Memandang nilai sebagai ukuran yang tepat mengenai prestasi sekolah; Anakanak pada masa ini gemar membentuk kelompok sebaya, biasanya untuk dapat bermain bersama-sama. (Abu Ahmadi \& Munawar Soleh, 2005, p 38-40)

Dapat dilihat bahwa anak pada tahap ini ingin hidup bebas tanpa ada hambatan, ingin mengetahui semua yang terjadi dialam sekitarnya, dan ingin dirinya di bantu oleh orang lain untuk menyelesaikan segala tugas dan pekerjaannya.

\section{Tujuan Sekolah Minggu}

Dalam sekolah minggu ada tujuan yang harus dicapai, dan tujuan sekolah minggu ialah anak-anak atau manusia harus mengenal Allah sebagai pencipta kehidupan dialam ini, dan didalam Yesus Bapa berkarya untuk menyelamatkan manusia, yang paling penting adalah pengenalan akan roh kudus yang mau bekerja dalam diri mereka, dan gereja adalah pusat dimana manusia bisa bertumbuh, mendidik anak-anak, orang muda dan orang dewasa supaya menjadi anggota Anggota gereja yang rajin, setia dan bertanggung jawab menilai segala sesuatu bersarkan Injil Kristus.

\section{Peran dan fungsi Sekolah Minggu}

Peran dan fungsi sekolah minggu sangat penting bagi para pengelolah dalam menyelenggarakan kegiatan sekolah minggu. Peran tersebut antara lain: pekabaran injil, alat penjangkau dan penyalur berkat. Masing-masing peran mempunyai tujuan yang akan diwujudkan melalui kurikulum, silabus, dan bahan ajar yang akan dipakai dalam proses kegiatan sekolah minggu. Sekolah minggu berperan penting dalam memenuhi kebutuhan anak pemenuhan tersebut ialah mengajarkan firman Tuhan kepada anak, menentukan anak-anak mengenal keselamatan melalui iman kepada Tuhan, dan melengkapi anak-anak untuk setiap perbuatan yang baik.

Dari penjelasan tentang peran dan fungsi sekolah minggu maka 
penulis berpendapat bahwa sekolah minggu dapat berjalan dengan baik jika sekolah minggu diprogramkan dengan baik dan mendapat dukungan dari pihak gereja dan semua orang tua yang mempunyai anak sekolah minggu. Gereja, jemaat dan semua komisi yang ada harus berperan dalam melakukan tugas masing-masing agar peran dan fungsi sekolah minggu dapat mencapai tujuan yang di harapkan.

Sekolah Minggu Sebagai Lembaga

\section{Pendidikan}

Sekolah minggu sesunggunya adalah sekolah yang dilaksanakan pada hari minggu, itu artinya sekolah minggu memang merupakan sekolah atau sebagai lembaga pendidikan. Untuk memajukan sekolah minggu perlu diperhatikan faktor-faktor yang mempengaruhi belajar dan prestasi belajar. Menurut Sumandi Suryabrata yaitu faktor internal dan eksternal, khususnya faktor eksternal. (Sumandi Suryabrata, p 233)

\section{Faktor lingkungan keluarga}

Sosial ekonomi keluarga

Bagi sekolah minggu yang ada diperkotaan dengan keadaan sosial ekonomi keluarga menengah keatas kesempatan mendapatkan fasilitas belajar yang lebih baik beda dengan sekolah minggu yang ada di pedesaan.

\section{Pendidikan orang tua}

Orang tua yang menempuh pendidikan tinggi cenderung lebih memperhatikan memahami pentingnya pendidikan agama khususnya sekolah minggu bagi anak-anaknya, dibandingkan dengan yang mempunyai jenjang pendidikan yang lebih rendah.

Perhatian kelaurga dan suasana hubungan antara anggota keluarga

Dukungan dari keluarga merupakan suatu modal besar anak mengenal, mencintai dan belajar di sekolah minggu. Dukungan dalam hal ini bisa secara langsung, berupa perhatian, pujian atau nasihat, maupun secara tidak langsung, seperti hubungan keluarga yang harmonis.

\section{Faktor linkungan sekolah}

Sarana dan prasarana :

Kelengkapan fasilitas sekolah minggu, seperti papan tulis, laptop, LCD, panggung boneka, papan panel dan kotak pasir, akan membantu kelancaran proses belajar mengajar di sekolah, selain itu ruangan dan lingkungan sekitar sekolah minggu juga dapat mempengaruhi proses belajar mengajar. 


\section{Kompetensi guru dan siswa}

Kualitas guru dan siswa sangat penting dalam memaksimalkan misi sekolah minggu, kelengkapan sarana dan prasarana tanpa disertai kemampuan guru dan siswa akan sia-sia belaka. Bila seorang siswa merasa kebutuhannya terpenuhi dengan cara guru mengajarkan pelajaran sekolah minggu dengan baik maka proses belajar mengajajar akan berjalan dengan baik. Dengan demikian anak akan terdorong untuk hadir dan belajar di sekolah mnggu.

\section{Kurikulum dan metode mengajar}

Hal ini meliputi materi dan bahan ajar bagaimana memberikan materi tersebut kepada anak, kurikulum yang dipakai dalam sekolah minggu pada umumnya adalah mengikuti kurikulum yang dikeluarkan oleh yayasan pemembina pekebaran injil Indonesia batu malang, melalui pedoman buku ini guru sekolah minggu bisa mengajar anak dengan baik dan sempurna.

Dasar Alkitabiah Pelayanan Sekolah Minggu

Dalam Perjanjian Lama, pada masa perjanjian lama ulangan 6:6-9, Apa yang kuperintahkan kepadamu pada hari ini haruslah engkau perhatikan, haruslah engkau mengajarkannya berulang-ulang kepada anak-anakmu dan membicarakannya apabila engkau duduk di rumahmu, apabila engkau sedang dalam perjalanan, apabila engkau berbaring dan apabila engkau bangun. Haruslah juga engkau mengikatkannya sebagai tanda pada tanganmu dan haruslah itu menjadi lambang di dahimu, dan haruslah engkau menuliskannya pada tiang pintu rumahmu dan pada pintu gerbangmu.

orang tua diperintahkan untuk mengajar anak-anak tentang perintah dan ketetapan Tuhan. Pada setiap hari sejak anak-anak lahir sampai anak-anak menginjak usia dewasa. Orang tua bertanggung jawab untuk mengajar dan mendidik anak-anak berdasarkan nilainilai kehidupan kristen. (E. Daniel Fountain, 2013.p 2 )

Orang tua wajib mengirim anakanaknya yang berusia dibawa lima tahun kesinagoge untuk didik oleh guruguru sukarelawan yang mahir dalam kitab Taurat. Anak-anak dikelompokkan dengan jumlah masingmasing 25 orang dan dibimbing untuk aktif berpikir dan bertanya, sendangkan 
guru menjadi fasilitator yang selalu siap sedia menjawab pertanyaan mereka.

Dalam Perjanjian Baru, tradisi mendidik anak-anak secara ketat terus berlangsung ketika Yesus berumur 12 tahun sampai pada masa rasul-rasul dan gereja mula-mula. Namun tempat mendidik anak perlahan-lahan tidak lagi dipusatkan di sinagoge tetapi di Gereja, tempat jemaat berkumpul, contohnya dalam 2 Timotius 3:15. Tradisi mengajar anak tidak berarti bahwa peran orang tua khususnya ayah telah diabaikan sama sekali, misalnya dalam Efesus 6:4 Dan kamu, bapa-bapa, janganlah bangkitkan amarah di dalam hati anak-anakmu, tetapi didiklah mereka di dalam ajaran dan nasihat Tuhan. Semua ayah diperintahkan untuk mendidik anak mereka dalam ajaran dan nasehat Tuhan.

Tujuan dari pendidikan spiritual kepada anak sekolah minggu adalah proses pembelajaran yang mengajakan agama kepada anak agar dapat memenuhi kebutuhan anak sekolah minggu yang dalam sehingga anak makin mengenal Tuhan dan juruselamatnya. Tujuan atau sasaran lain dari pendidikan spiritualitas ini, adalah mengajarkan anak-anak tentang bagaimana hidup sesuai dengan firman Tuhan atau hidup yang takut akan Tuhan.

\section{KESIMPULAN}

Bisa dilihat bahwa guru sekolah minggu mempunyai tanggung jawab yang besar terhadap perkembangan spiritual anak sekolah minggu, ada baiknya jika orang tua dan gereja juga terlibat langsung dalam mendidik anak agar semua anak dapat ikut serta dan aktif dalam pelayanan pondok gembira dan sekolah minggu.

Guru sekolah minggu juga harus sadar bahwa mendidik anak sangatlah penting, sehingga anak-anak sekolah minggu mendapatan pelayan yang sangat baik. melalui pendidikan spiritual yang adalah jembatan menuju pada pendidikan spiritual diharapkan agar anak sekolah minggu menjadi anak-anak yang dengar-dengaran terhadap orang tua, mengasihi teman, berbuat baik, dan hidup sesuai dengan peraturan Tuhan.

\section{DAFTAR PUSTAKA}

Agus M Harjana, Relegiositas, Agama \& Spiritualitas, (2005). Yogyakarta Kanisius. 
Andar Ismail , (2006). Ajarlah mereka melakukan-kumpulan karangan seputar PAK, Jakarta : BPK Gunung Mulia.

Daniel Nuhamara PAK Dewasa, Bandung : Jurnal info media.

E. Daniel Fountain, (2013). Mendidik Anak menurut jalan Tuhan, Jakarta : Rineka Cipta.

E.G Homrighausen \& I.H Enklaar, (2011). Pendidikan Agama Kristen, Jakarta: BPK Gunung Mulia.

Erika Helena, \& Sudi Ariyanto, (2003). Menciptakan Sekolah Minggu yang Menyenangkan. Yogyakarta: Gloria Graffa.

Jhon M Nainggolan, (2007). Menjadi Guru Agama Kristen, suatu upaya peningkatan mutu dan kualitas profesi Keguruan, Jabar: Generasi Info Media.

Junihot Simanjuntak, (2012). Setiap Anak bisa Pintar, Yogyakarta ANDI

Khoe Yao Tung, (2013). filsafat pendidikan Krisren, Yogyakarta: ANDI

Menjadi Ngainun Naim, ( 2011) Memberdayakan dan Mengubah Jalan Hidup Siswa, Yogyakarta: Pustaka pelajar.

Pusat Bahasa Depertemen Pendidikan Nasional,Kamus Besar Bahasa Indonesia, Edisi Ketiga, Jakarta: Balai Pustaka, 2003.

Ralph M. Ringgs. (1978). Sekolah Minggu Yang Berhasil, Gandum Mas
Robert Boelkhe, (2002). Memperlengkapi bagi pelayanan dan pertumbuhan, Jakarta : BPK Gunung Mulia.

Sugiyono, (2009). Metode Penelitian Kuantitatif,Kualitatif, Bandung : Alfabata.

Undang Undang perlindungan Anak UU RI No 23 th 2002, penerbit Sinar Grafika, Jakarta 2003

W. Robert Pazmino, (2012). Fondasi Pendidikan Kristen. BPK Gunung Mulia 